LAERE MIDDEL ODK

\title{
Teknologiforståelse i fag
}

Af Marie Falkesgaard Slot, Stig Toke Gissel \& Mikkel Hjorth

Korrekt citering af denne artikel efter APA-systemet (American Psychological Association System, 7th Edition):

Slot, M. F., Gissel, S. T., \& Hjorth, M. (2021). Teknologiforståelse i fag. Learning Tech - Tidsskrift for læremidler, didaktik og teknologi, (10), 191-217.

DOI 10.7146/It.v6i10.125676 
Artiklen bygger på et interviewstudie med faglige udviklere i afprøvningsforsøget i teknologiforståelse i folkeskolen (UVM, 2018-2021). Målet med studiet er at afdække udviklernes erfaringer med transformation af teknologiforståelse til prototyper (undervisningsforløb) i eksisterende skolefag. Artiklen peger på baggrund af udviklernes fortolkninger på fire potentielle barrierer for et reelt fagmøde og dermed for integration af teknologiforståelse i eksisterende fag: Manglende samtænkning af begreber og fagsprog, divergerende definitioner af teknologi, manglende overlap og relevans i tildelingen af delelementer af fagligheden og manglende plads til faglig udvikling.

The article is related to a national experiment, where a new school subject Technology Comprehension (UVM, 2018-2021) was applied and tested in 4.6 different schools. The aim of the study is to uncover the developers' experiences with the transformation of Technology Comprehension into prototypes with special focus on themes such as interdisciplinarity, technology, subject language, and interaction etc. The article concludes that the competences must "fit" within the development potentials of the subjects. The study also points out a significant difference between how developers in arts, the humanities, and the natural sciences experienced the project. 


\section{Teknologiforståelse i fag}

Den digitale udvikling har øget behovet for, at skolen udvikler elevers kompetencer, så de kan forstå og navigere reflekteret og kyndigt i den digitale verden. I Danmark har vi taget hul på den vigtige drøftelse af, hvad indholdet i fagligheden i teknologiforståelse skal være, hvordan denne faglighed skal organiseres i skoleskemaet, og om denne faglighed skal have status af et selvstændigt fag, eller om den skal integreres i den eksisterende fagrække. I international sammenhæng er ambitionen om at afprøve integrationen af en faglighed, der skal styrke elevers forståelse af teknologi som faglighed og i den eksisterende fagrække både speciel og nytænkende.

Denne artikel er baseret på et interviewstudie af faglige udvikleres erfaringer med i 2018-2021 at udvikle undervisning i Forsøg med teknologiforståelse i folkeskolens obligatoriske undervisning (tekforsøget). Fokus for artiklen er den forståelse, som de fagudviklere, der har eksperimenteret med "integration af teknologiforståelse i eksisterende fag" har udviklet i forsøgsperioden (BUVM, 2018b). Udviklerne har haft det faglige ansvar for at transformere læreplansdokumenter (mål, læseplan og vejledning og herunder nye kompetence- og f/v-områder (færdigheds- og vidensområder) til såkaldte prototyper eller undervisningsforløb. Forsøgsfagligheden er blevet afprøvet på 46 folkeskoler i Danmark. I forsøget har 36 fagudviklere med udgangspunkt i læreplansdokumenterne udviklet 110 prototyper på undervisningsforløb til skolerne. Lærerne fra forsøgsskolerne har efter en kort introduktion afprøvet forløbene i deres egen praksis, og fagudviklerne har under besøg på skolerne og ved centrale samlinger haft dialog med lærerne, der deltog i forsøget.

På den baggrund har vi opstillet følgende forskningsspørgsmål:

Hvilke erfaringer har faglige udviklere i afprøvningsforsøget haft med at transformere teknologiforståelse som forsøgsfaglighed i eksisterende fag set gennem temaer som tværfaglighed, begreber og fagsprog, teknologi, samspilsmuligheder og brudflader? 


\section{Fagligheden og forsøg med fagligheden}

I afprøvningsforsøget for teknologiforståelse, som artiklen er baseret på, introduceres teknologiforståelse som en ny faglighed i folkeskolen, der tager udgangspunkt i digital teknologi og dennes betydning for elever og borgere i et digitaliseret samfund. I Danmark har vi i det tværgående tema "It og medier" i skolen (BUVM, 2021b) ligesom næsten alle lande i EU et særskilt fokus på digitale kompetencer (EACEA, 2012). Den faglighed, som afprøves i forsøget med teknologiforståelse, er beskrevet af en rådgivende ekspertskrivegruppe nedsat af Børne- og Undervisningsministeriet (BUVM). Af kommissoriet for denne ekspertskrivegruppe fremgår det, at forsøget skulle "afprøve forskellige modeller for styrkelse af teknologiforståelse som en obligatorisk del af undervisningen i folkeskolen..." (BUVM, 2018a). Samtidig beskrives, at forsøgets baggrund er, at den hastige teknologiske udvikling har betydning for skolens muligheder for at leve op til de alment dannende elementer i folkeskolens formålsparagraf, samtidig med at der henvises til, at EU og OECD har fokus på fremtidens kompetencer. Det fremhæves i kommissoriet, at "faget skal være almendannende, kreativt og skabende" (BUVM, 2018a), og der citeres fra folkeskolens formålsparagraf stk. 3 , hvor det er angivet, at skolen "skal forberede eleverne til deltagelse, medansvar, rettigheder og pligter i et samfund med frihed og folkestyre." (BUVM, 2021a). Forsøgsfaget Teknologiforståelse er beskrevet i fire kompetenceområder: Digital myndiggørelse, digital design og designprocesser, computationel tankegang og teknologisk handleevne. Digital design og designprocesser sætter fokus på de kreative processer under, hvilke digitale artefakter tilvejebringes, herunder de valg og fravalg, som designeren har måttet foretage eller foretager i processen. Digital myndiggørelse sætter fokus på den indlejring af holdninger og værdier, som kan fremanalyseres i digitale artefakter. Teknologisk handleevne bidrager med et perspektiv, der giver sprog, udtryksevne og værktøjsmestring i forhold til at kunne udtrykke computationelle tanker i et digitalt artefakt. Computationel tankegang omhandler modellering af verden, så elementer kan eksekveres computationelt og skabe ny erkendelse eller ny mening i en (eksisterende) brugspraksis.

En række begreber har være rammesættende for fagudviklerens planlægning af undervisning i den nye faglighed i afprøvningsforsøget og defineres kort: Begrebet prototype defineres i projektet som en foreløbig udgave af et undervisningsforløb, hvis formål er at afprøve og teste idéer i et design. I projektet er alle 110 prototyper tilgængelige på tekforsøget.dk. Fagudviklerne henviser undervejs til en række begreber fra projektet. Selvom nogle af disse begreber har en forskningsmæssig historik, antager vi, at udviklerne primært henviser til 
begreberne i den ramme, de har haft i forsøget. I Figur 1 har vi kopieret begreber fra en ordliste (BUVM, 2019, der blev udviklet til projektet og de definitioner på begreberne, der var angivet i denne ordliste.

Figur 1.

Definitioner på anvendte begreber i forsøget.

\begin{tabular}{|c|c|}
\hline Digitalt artefakt & $\begin{array}{l}\text { Digitalt artefakt betegner en af mennesket tilvejebragt } \\
\text { genstand, som indeholder et væsentligt element af digi- } \\
\text { tal teknologi. Til forskel fra betegnelsen digital teknologi, } \\
\text { betoner betegnelsen digitalt artefakt de produktkvalite- } \\
\text { ter, der er blevet til gennem design og programmering, } \\
\text { hvorved intentionalitet og formål er blevet indlejret i } \\
\text { artefaktet. }\end{array}$ \\
\hline $\begin{array}{l}\text { Digitale } \\
\text { teknologier }\end{array}$ & $\begin{array}{l}\text { Digitale teknologier betegner i denne sammenhæng } \\
\text { et materiale, der har et væsentligt digitalt element. Til } \\
\text { forskel fra digitalt artefakt betegner digital teknologi det } \\
\text { potentiale, som det digitale materiale rummer i forhold } \\
\text { til at kunne indgå i en designproces, hvor digital tekno- } \\
\text { logi bruges til at udforme et digitalt artefakt. }\end{array}$ \\
\hline Intentionalitet & $\begin{array}{l}\text { Intentionalitet betegner de holdninger eller værdier, } \\
\text { som designere har indlejret i et digitalt artefakt. Alle di- } \\
\text { gitale artefakter sigter efter noget særligt eller har noget } \\
\text { særligt til hensigt. Designere har gennem valg og fravalg } \\
\text { i designprocessen besluttet, hvilke egenskaber et digitalt } \\
\text { artefakt skal have. }\end{array}$ \\
\hline $\begin{array}{l}\text { Komplekse } \\
\text { problemer }\end{array}$ & $\begin{array}{l}\text { Komplekse problemstillinger betegner en særlig kategori } \\
\text { af problemfelter, der ikke kan beskrives entydigt, og } \\
\text { hvortil der ikke kan skabes en entydig rigtig løsning. } \\
\text { Komplekse problemer er ofte kendetegnet ved mangel- } \\
\text { fulde eller modsatrettede informationer, som gør det } \\
\text { svært at forstå problemets omfang og format. }\end{array}$ \\
\hline
\end{tabular}

Begreberne har bidraget til en indledende forståelse af et fagsprog for teknologiforståelse og har samtidig været genstand for fag-faglige drøftelser af, hvad integrationen af nye kompetence- og f/v-områder i eksisterende undervisningsfag har betydet af muligheder og begrænsninger og hvordan de metodisk kunne udmøntes (Slot, Lorentzen \& Hansen, 2021). I Bilag 1 vises en tabel over de forskellige modeller for integration af kompetenceområder samt færdigheds- og vidensmål i de syv fag, som fagudviklerne har arbejdet med i afprøvningsforsøget. 


\section{Teknologiforståelse som forskningsfelt}

Sammenkoblingen af de fire kompetenceområder i teknologiforståelse er en særlig dansk konstruktion (Wagner, Iversen \& Caspersen, 2020), og derfor findes der ikke et enkelt forskningsfelt, som teknologiforståelse trækker på. Wagner et al. (2020) argumenterer for, at "... computational empowerment tilføjer en kritisk og nysgerrig stillingtagen til teknologien, og dens påvirkning af os som mennesker" (s. 11). I forlængelse af dette argumenteres i Wagner et al. (2020) for computational empowerment som en kobling mellem de to forskningstraditioner for henholdsvis computational thinking (Wing, 2006) og participatory design. Feltet participatory design har sin rod i forskning i, hvordan arbejdere kunne myndiggøres i forbindelse med digitalisering af de processer, de var ansat til at varetage (Ehn, 1988). Iversen, Dindler og Smith (2020) har skrevet om computational empowerment som en udmøntning af de myndiggørende tanker bag participatory design i en skolekontekst.

Med baggrund i participatory design har der i Danmark været en række forsøg med elevers designprocesser i makerspaces i skolen indenfor eksempelvis FabLab@School.dk-projektet (Smith, Iversen \& Hjorth, 2015; Hjorth, Christensen, Iversen \& Smith, 2017; Christensen, Hjorth, Iversen \& Smith, 2019). Sådanne forsøg har dels trukket på arven fra participatory design og dels på designforskning og interaktionsdesignforskning mere generelt (Cross, 2011; Löwgren \& Stolterman, 2004). Denne danske forskning kan ses som del af en strømning i retning af et større fokus på børns designprocesser inden for det internationale forskningsfelt Child-Computer Interaction (Iversen, Smith, Blikstein, Katterfeldt \& Read, 2015). Internationalt har fokus i forskningen imidlertid oftest været på design som et middel til elevers læring om digitale teknologier og programmering (se eksempelvis Katterfeldt, Dittert \& Schelhowe, 2015; Bekker, Bakker, Douma, Van Der Poel \& Scheltenaar, 2015; Chu, Angello, Saenz \& Quek, 2017; Brennan, 2015).

Computational Thinking (CT) har i forskningslitteraturen, såvel som i praksis, været anvendt med flere forskellige betydninger fra Wings (2006) overordnede beskrivelse af at kunne anvende computere til at løse problemer som en grundlæggende færdighed på linje med at kunne læse, skrive og regne til mere specifikke koncepter, praksisser og perspektiver som dem formuleret af Brennan og Resnick (2012). Barr og Stephenson (2011) tager sådanne koncepter helt ind i eksisterende fag som matematik og samfundsfag, og Weintrop, Beheshti, Horn, Orton, Jona, Trouille \& Wilensky (2016) undersøgte CT i matematik og naturfag som et forsøg på at integrere CT i disse fag i amerikanske ungdomsuddannelser. Igennem længere tids indsatser 
med CT i særligt den angelsaksiske skoleverden, har der efterhånden udkrystalliseret sig nogle indholdsområder, som sædvanligvis regnes til CT, men der mangler ifølge Caspersen, Iversen, Nielsen \& Mussaeus (2018) stadig klare resultater og evidens for, hvad CT er i en grundskolekontekst.

\section{Undersøgelsesdesign}

Vi har undersøgt den del af tekforsøget, hvor teknologiforståelse i eksisterende fag introduceredes som "En delmængde af en større faglighed udfoldet i det selvstændige fag" (BUVM, 2018b). De involverede fag fordelt på alderstrin var:

— I indskolingen: Matematik, dansk, natur/teknologi og billedkunst.

- På mellemtrinnet: Matematik, dansk, natur/teknologi samt håndværk og design.

— I udskolingen: Matematik, dansk, fysik/kemi og samfundsfag.

Vores empiri er skabt gennem interviews med de fagudviklere, der har udarbejdet prototyper på undervisningsforløb. I seks fokusgruppeinterview har vi interviewet $i$ alt 16 fagudviklere ud af $i$ alt 19 deltagere. I samfundsfag har vi haft mulighed for at interviewe en fagudvikler, mens vi interviewede fire udviklere i dansk, tre i natur/teknologi, to i billedkunst og to i håndværk og design. I fagene natur/teknologi, fysik/kemi deltog i alt tre deltagere i det samme fokusgruppeinterview. Interviewene er foretaget i december 2020, hvilket var efter endt udvikling af de sidste undervisningsforløb men umiddelbart før de sidste afprøvninger af forløbene på skolerne. Under interviewet blev fagudviklerne spurgt til deres erfaringer med at transformere den nye teknologiforståelsesfaglighed ind i eksisterende fag.

Interviewene er efterfølgende transskriberet og kodet efter en struktur, hvor hvert tema er koblet til en række kategorier, som er genereret på basis af mønstre i informanternes udsagn, hvorved vi har forsøgt at være åbne for at lade undersøgelsespersonernes perspektiver bestemme, hvad der er centralt (Maykut \& Morehouse, 1994). Desuden er analysen deskriptiv snarere end teorigenererende (Potter, 1996). Eksempler på kategorier er for eksempel "udviklerens erfaringer med teknologiforståelsesfagligheden" eller "vurdering af begreber og fagsprog". De tilsammen godt 120 siders interview er derefter gennemgået "line by line" (Creswell, 2008) af to forskere, som har kodet datamaterialet for alle kategorier. Fagudviklerne, som er informanter i forhold til undersøgelsen, har kommenteret analysen af deres inter- 
view, hvilket bidrager til, at artiklens udlægning af data er retvisende i forhold til interviewpersonernes holdninger og perspektiver.

\section{Når to fagligheder mødes}

I det følgende præsenterer vi udviklernes erfaringer og opfattelse af integrationen af teknologiforståelse med det fag fra den etablerede fagrække, som udviklerne har repræsenteret i forsøget. Vi definerer erfaring på et fænomenologisk grundlag, hvor den centrale tilgang er subjektiviteten og erfaringens unikke position. Undersøgelsesdesignet og det analytiske bidrag har ikke haft til formål at få udviklerne til at fremstå negativt eller som en gruppe, der ikke har de fornødne kompetencer til at udvikle fagligheden. Vi interesserer os for udviklernes italesættelse og forståelse af, om de to fagligheder er kompatible, hvilke elementer der har skabt sammenstød, og hvor de ser potentialerne og udfordringer i dette faglige møde. I en åben kodning af de transskriberede fokusgruppeinterviews med fagudviklere fra forsøget opstod der fem temaer, som udfoldes i de næste afsnit.

\section{Tema 1: Det tværfaglige møde mellem det etablerede fag og teknologiforståelse}

Der er stor forskel på, hvordan udviklerne ser på mødet imellem deres eget fag og teknologiforståelsesfagligheden. Hvor for eksempel natur/ teknologi og fysik/kemi oplevede, at de to fagligheder passede "rigtigt godt sammen", og at der primært var brug for udvikling af materialer, didaktik og fælles forståelser, omtalte udviklerne fra dansk teknologiforståelse som "et selvstændigt fag, der skal proppes ind i vores fag". Fagudviklerne fra dansk så hellere, at der havde været lagt op til en fortsat fagudvikling i løbet af forsøget, så "vi også udviklede faglighed i mødet med danskfaget". Fagudviklerne har desuden haft svært ved ud fra styringsdokumenter at få greb om fagligheden: "Hvad er det nye? Hvad er det egentligt vi skal? Hvad er teknologiforståelse i dansk?” Udviklerne veksler altså mellem at beskrive teknologiforståelse som noget, der allerede er i danskfaget og noget fremmed, der proppes ind. Udviklerne omtaler desuden, at de i deres samarbejde med lærere i forsøget har oplevet samme skisma blandt disse. Dels har lærere omtalt (elementer af) teknologiforståelse, som noget de gjorde i forvejen, og dels har de omtalt dansk og teknologiforståelse som to forskellige fagligheder, "hvor den sidste, den er en fremmed fugl, der er på besøg" (udvikler i dansk).

Som beskrevet, var der i forsøget meget forskellige modeller for 
integrering af teknologiforståelse i fagene. Hvor håndværk og design for eksempel havde fået tildelt et enkelt kompetenceområde (digital design og designprocesser), havde natur/teknologi i forsøget fået tildelt en sammensætning af færdigheds- og vidensområder fra alle fire kompetenceområder som et nyt kompetenceområde. En matematikudvikler reflekterede over, at dette gav "(...) mulighed for at arbejde helhedsorienteret i natur/teknologi (...)", og gjorde, at man som underviser "ikke skal vente på et tværfagligt forløb (...)" for at kunne "(...) arbejde helhedsorienteret i natur/teknologi (...)". For denne fagudvikler har det altså været vigtigt, at der i natur/teknologi var lavet en sammensætning af færdigheds- og vidensområder fra alle fire kompetenceområder i teknologiforståelsesfagligheden. Udvikleren mener, det burde gælde integrationen i de andre fag også: "Der er en helhed i teknologiforståelse, som jeg synes er vigtigt at få skrevet ind i alle fag."

I billedkunst taler fagudviklerne om behov for en gentænkning af mødet mellem teknologiforståelse og deres fag, der har en mere "elastisk tilgang og mere lydhørhed overfor, hvor fagligheden kan bringes hen på længere sigt". Udviklerne er særligt optagede af, at udmøntningen af faget har "(...) føltes afkoblet fra andre typer af faglige tænkninger end den matematisk-logiske". Udviklerne i billedkunst peger ligesom danskudviklerne på, at der ikke har været skabt plads til at afprøve faglige metodiske tilgange, og at konsekvenserne har været, at fagets egne metodiske tænkninger med relevans for teknologiforståelse ikke er blevet afprøvet. I håndværk og design så udviklerne fællesmængder mellem teknologiforståelsesfagligheden og deres fag. Som begrundelse for dette pegede udviklerne blandt andet på, at faget er "meget praksisfagligt", at "man laver produkter" og at der er noget med "kulturforståelsen, altså hvad er det for en kontekst, der her skal bringes ind i, som jeg også synes hænger meget godt sammen".

Den interviewede udvikler i samfundsfag oplever flere fællesmængder mellem teknologiforståelsesfagligheden og faget, og at den nye faglighed kan berige samfundsfaget: "Altså, det er ikke totalt skævt i forhold til den faglighed, vi arbejder med traditionelt, (...) men det tilføjer noget nyt og anderledes". Samtidig pegede udvikleren på, at "der er ting hvor faget ikke har fulgt med". Til gengæld oplevede udvikleren i lighed med nogle af de andre fag kravet om, at der skal designes et digitalt artefakt som et "benspænd".

Når man ser på tværs af fagene i forsøget, er det altså tydeligt, at der er forskel på, hvordan fagudviklerne har oplevet mødet mellem teknologiforståelsesfagligheden og deres fag. Mens der har været fællesmængder mellem disse i håndværk og design, samfundsfag, natur/teknologi og fysik/kemi, har især billedkunst og dansk oplevet teknologiforståelse som en faglighed, der har været vanskelig at få til at fungere i sin nuværende udformning, og udviklerne fra begge fag 
har efterlyst, at det gentænkes, hvordan teknologiforståelse skal indgå i deres fag, mens særligt udviklerne fra natur/teknologi og fysik/kemi peger på behovet for udviklingstid og for udvikling af fælles forståelser, der på sigt kan blive til de første elementer i en egentlig integrativ, fagdidaktisk tænkning om teknologiforståelse i naturfagene.

\section{Tema 2: begreber og fagsprog}

I forsøget er det løbende blevet problematiseret, at der i teknologiforståelsesfagligheden var tale om et nyt og vanskeligt fagsprog (se eksempelvis BUVM, 2020; Slot, Lorentzen og Hansen, 2021), hvilket også medførte, at der undervejs i forsøget blev udarbejdet en ordliste med yderligere forklaringer. Ikke overraskende var der også blandt udviklerne en opmærksom på faglighedens begreber og fagsprog samt på, hvordan disse passede med nærtstående begreber i de eksisterende fag.

I natur/teknologi og fysik/kemi pegede udviklerne på, at lærerne havde haft svært ved computationel tankegang som begreb, før der var opnået en fælles sproglig erkendelse af sammenhænge mellem for eksempel teknologisk handleevne og de tankegange, som den computationelle tænkning repræsenterer: "Det slog bare ikke rigtig an." Desuden problematiserede udviklerne i natur/teknologi og fysik/kemi det fokus, der havde været på komplekse problemstillinger i forsøget, idet man gerne i faget ville have haft plads til også at "tage udgangspunkt i en fantasi eller en idé eller noget, man forestiller sig”. For udviklerne var der en modsætning imellem sådan en tilgang og så den fra forsøget, hvor de oplevede komplekse problemer som nogle, der var svære eller umulige at løse for elever, og hvor de derfor efterlyste mere konkrete problemstillinger:

99

Eleverne skal bekæmpe temperaturstigning og oversvømmelser og sådan noget og det er altså svært at forholde sig til, når man sidder i Tvis på en landsbyskole øhm... det har været en udfordring at gøre det mere konkret og måske tage fat i mindre udfordringer. Men det, tror jeg, bliver sjovere for eleverne, fordi de kan se, at de løser et konkret problem og ikke noget, der over 30 års spænd kommer til at sænke vandstanden 1,5 centimeter.

Også udviklerne i natur/teknologi problematiserede den måde komplekse problemer har været i forsøget. Udviklerne oplevede, at dette havde skabt et fokus på en "bredere problemstilling", som havde ledt dem "væk fra fag-fagligheden". Desuden mente udviklerne i mate- 
matik, at begreberne fra teknologiforståelse har skabt distance hos lærerne i forsøget: "mange elementer i teknologifagligheden lapper fuldstændig ind over matematikken, men der bliver brugt andre begreber". En af udviklerne har løst det ved ikke at stå så hårdt på begreberne, men i stedet lægge indhold ind i forløbene uden at eksplicitere, hvad det ville hedde med teknologiforståelsesbegreber:

99

Så nogle gange tror jeg også det handler om hvad man anser for computationel tankegang. Og i mine egne forløb har jeg også selv gjort alt hvad jeg kunne for at skrive det frem, for eksempel med rutediagrammer og input, databehandling, outputdiagrammer og sådan nogle ting, så jeg tror, de [lærerne] har arbejdet med det, og det har været indlysende for dem, jeg tror bare ikke, de ser det som computationel tankegang.

Mens fagudviklerne i matematik havde oplevet, at lærerne havde haft svært ved det nye begreb computationel tankegang, oplevede fagudviklerne i danskfaget problemer ift. begrebet intentionalitet, som både findes i teknologiforståelsesfagligheden og i dansk, men som ifølge fagudviklerne betyder noget forskelligt i de to fagligheder. Tilsvarende diskuterede gruppen en uklarhed i forhold til forskelle mellem de digitale artefakter, som var produkter i teknologiforståelse og det udvidede tekstbegreb, som danskfaget indeholder. Udviklerne i dansk oplevede samlet set, at mødet mellem de to fagligheders begreber blev på teknologiforståelses præmisser: "Det har været svært, når der allerede er genstande i danskfaget som sagtens kan tilgodese teknologiforståelses-målene, og (forsøgs)projektet har villet en anden vej”.

Ydermere har gruppen af udviklere til dansk den holdning, at også designprocessen defineres for snævert i læreplanerne. En udvikler foreslår således, at designprocessen fra teknologiforståelse lægges "ind under" det danskfaglige kompetenceområde 'Fremstilling', "Fordi det er en udbygning af det vi gør i forvejen, og det vil også gøre at læreren (...) bedre kan genkende det". Således arbejdes der ifølge udviklerne allerede med iterative designprocesser, særligt tydeligt i procesorienterede skriveforløb, og "med at udvikle eleverne til at være kritiske over for budskaber og sproglige ytringer på sociale medier eller i andre tekster" i danskfaget. Udviklerne ser således langt hen ad vejen forskellen mellem faglighederne som især begrebslig, idet fagtermer fra teknologiforståelse skaber en distance til noget af det, man i fagudviklernes øjne i forvejen gør i dansk, men som blot kaldes noget andet i læreplanen for teknologiforståelse.

De danskdidaktiske udviklere har desuden svært ved at forlige sig med, at teknologiforståelsesfagligheden, som den er formuleret i læreplansdokumenterne, er forbundet med en computational empowerment-tradition, som foreskriver, at man i undervisningen skal 
arbejde med at løse komplekse, samfundsmæssige problemstillinger gennem digital fabrikation. En udvikler betegner læreplanens intentioner som repræsenterende en "ikke-humanistisk tænkning" og uddyber: "det ligger så langt fra vores fag at være et fag, der skal løse problemer i virkeligheden" på en "håndgribelig, konkret" måde, som udviklerne også benævner "erhvervsrettet". Som i billedkunst kan faget ifølge de danskdidaktiske udviklere noget andet i forhold til at forstå og agere i verden: "danskfaget er også det at kunne forestille sig nogle andre virkeligheder. Eller at kunne fantasere sig til, at tingene kunne være anderledes, og sproget kunne bruges anderledes til at skabe verdenen med." En udvikler efterlyser eksplicit en bredere opfattelse af, hvad teknologiforståelse i forhold til undervisning skal være i læreplansdokumenterne: "Hvorfor er der ikke plads til teknologifilosofi? Hvorfor er der ikke plads til teknologihistorie? Hvorfor er der ikke plads til forholdet mellem menneske og teknologi?”

Samlet set, har udviklerne på tværs af en række fag oplevet forskellige vanskeligheder med begreber og fagsprog fra teknologiforståelsesfagligheden. I matematik, natur/teknologi og fysik/kemi oplevede fagudviklerne, at det tog tid for lærerne at tilegne sig indsigt i begreberne, mens fagudviklerne i dansk og matematik pegede på, at mange begreber overlappede, men at det enten skabte distance til lærerne at bruge nye ord for det samme, eller at det gav problemer at bruge de samme ord på andre måder.

\section{Tema 3: definitioner af teknologi}

Det tredje tema i fagudviklernes besvarelser er definitioner af teknologi. Mens man i natur/teknologi og fysik/kemi i begyndelsen af forsøget oplevede de digitale teknologier som en barriere for nogle lærere, har forventningen om produktion af digitale artefakter givet mening for disse udviklere:

99

Hvor det ofte er personbåret, hvis der er en fysiklærer, der har særlig interesse i digital teknologi, så bliver de[t] måske inddraget der, nu er man ligesom tvunget ud i det, og det synes jeg faktisk, forsøget har vist, at det kan godt lade sig gøre.

Gruppen beskrev en positiv udvikling i lærernes evne og lyst til at håndtere digitale teknologier og udvikle digitale artefakter over tid, samtidig med, at lærernes spørgsmål forandrede sig fra, at de i starten handlede om teknologi, "men nu er vi begyndt at få de der refleksioner over teknologien, mere de der mere digital myndiggørelsesrefleksioner i virkeligheden, ikke, eller begyndt at diskutere hvordan vi bruger 
den, og hvorfor vi bruger den".

For fagudviklerne i dansk, er definitionen af, hvad et digitalt artefakt var, til gengæld blevet opfattet som snæver, og som noget der nogle gange føltes irrelevant i forhold til danskfaget: "Vi prøvede jo meget at sige, kan et digitalt artefakt ikke også være en PP-præsentation, kan det ikke også være en film? Altså nogle af de ting vi i forvejen arbejder med?". Udviklerne gav udtryk for, at en sådan opblødning i forhold til, hvilke produkter, der var krav om, kunne lette integrationen i dansk, hvor der ifølge fagudviklerne i forvejen var opbygget en praksis for elevers arbejde med digitale artefakter i et sådant perspektiv. Udviklerne havde både mødt lærere, der opfattede teknologiforståelse som et rent programmeringsfag og lærere, der opfattede teknologiforståelse som noget, de allerede gjorde i dansk (uden at programmere). En af udviklerne gav udtryk for, at lærerne ikke havde udviklet en ny forståelse for teknologi i løbet af forsøget. Ligesom i dansk problematiserede udviklerne i billedkunst definitionen af et digitalt artefakt og omtalte det som, at de havde været "i clinch med det her digitale artefakt-begreb." Samtidig oplevede fagudviklerne, at det at begrænse fagligheden til digital teknologi, førte til en forsimpling af faget, og de oplevede begrebsapparatet fra teknologiforståelse som "lidt af en sten i skoen for mange andre typer faglige tænkninger. Selvom der også i gruppen var en optagethed af at undersøge, hvori det nye teknologifaglige bestod og hvilke typer af artefakter, som reelt kunne bidrage med noget nyt, oplevede udviklerne i billedkunst ikke, at fortolkningen af teknologisk handleevne eller "kodedelen" havde tilført noget til det eksisterende It og medie-perspektiv i faget. Omvendt var det fokus på digital billedbehandling, som forsøget har givet anledning til, ifølge udviklerne en nødvendighed i billedkunstfaget og noget nogle lærere har haft berøringsangst i forhold til. Billedkunstfaget har dermed brug for det nye input fra teknologiforståelse:

99

... det er jo et udvidet fagbegreb, vi har gang i, ikke også, vi er ved at transformere et fag. Men jeg synes vi svigter teknologiforståelsesfaget, jeg synes vi svigter vores børn, hvis vi tager den visuelle dimension ud, som ligger i billedkunst.

Generelt så udviklerne store potentialer i mødet mellem de to fagligheder, men de oplevede samtidig, at begreberne var definerede, så mødet skete på teknologiforståelsesfaglighedens præmisser og ikke på billedkunsts ditto.

I håndværk og design problematiserede udviklerne også definitionen af et digitalt artefakt i forsøget. Som et eksempel pegede udviklerne på, at de ifølge undervisningsvejledningen skal arbejde med digitale fabrikationsteknikker (som eksempelvis 3D-printer), 
men at dette produktionsarbejde først blev defineret som et digitalt artefakt, "når vi integrerer noget digitalt i de digitale artefakter, altså i de fysiske artefakter." De oplevede denne måde at definere et produkt i teknologiforståelse som uoverensstemmende med den forståelse af produktionsprocesser, som i forvejen var i håndværk og design.

I samfundsfag efterlyste den ene udvikler en begrebsafklaring af, hvad teknologiforståelse er i samfundsfag, og underbyggede den manglende afklaring: "Helt klart er det jo godt at lære om hvad programmering er, og programmering og digitale artefakter ... men det er ikke det, der mangler, når vi taler, hvad hedder det, samfundsfag, det synes jeg ikke, det er ikke....' Udvikleren gav udtryk for, at samfundsfaget allerede i sig selv havde en teknologiforståelse, som ikke harmonerede med den i læreplansteksten for forsøgsfaget: "Det er jo ikke den samfundsfaglige teknologiforståelse, der er lagt op til i forsøgsfaget". Udvikleren var for eksempel ikke tilfreds med den måde kompetenceområdet digital myndiggørelse var beskrevet på i forhold til samfundsfag, da hun ikke så læseplanens beskrivelse dække den politiske eller samfundsmæssige dannelse, udvikleren gerne så. Som et eksempel på dette, pegede udvikleren på færdigheds- og vidensområdet teknologianalyse: "samfundsfagligt ville en teknologianalyse jo handle om, hvordan den her teknologi påvirker vores samfund".

Samlet set pegede en del af udviklerne på, at definitionen af digitale artefakter har været svær at få til at fungere ind i de eksisterende fagligheder. I natur/teknologi og fysik/kemi berettede udviklerne til gengæld om, at selvom kravene til digitale artefakter i starten havde været en barriere, var der i løbet af projektet sket en udvikling, og på at kravene havde været nødvendige for denne udvikling. I dansk, håndværk og design, billedkunst og samfundsfag oplevede udviklerne til gengæld definitionen af et digitalt artefakt som snævert og snærende.

\section{Tema 4: Kompetence-, færdigheds- og videns- områder i fagene}

Som tidligere beskrevet var hvert fag blevet tildelt en delmængde af de samlede færdigheds- og vidensområder fra forsøgsfagligheden. Der var blandt udviklerne forskellige holdninger til, hvorvidt denne tildeling havde fungeret hensigtsmæssigt. I natur/teknologi og fysik/ kemi havde man især fået tildelt færdigheds- og vidensområder fra "digital design og designprocesser" og "computationel tankegang". Ifølge udviklerne havde sammensætningen af områder fra de to kompetenceområder gjort, "at man har ku' få det hele med". Dels oplevede udviklerne, at de to kompetenceområder spillede godt sammen i sig selv, 
men de oplevede også, at der var et godt samspil med naturfagsfagligheden: "Altså, der er nogle mål, som man ikke behøver tænke, at det er teknologiforståelse, man kan bare være faglærer, hvor man tænker: 'nå, men det passer fint ind i den forståelse, jeg allerede har af mit fag.' Som et eksempel var arbejdet med data en del af computationel tankegang, som fagudviklerne fandt relevant: "Hele det her med data, altså jeg tænkte, det er måske det fag, hvor vi har størst mulighed for rent faktisk at få nogle reelle data, altså at måle på et eller andet”. Udviklerne er samtidig inde på, at selvom digital myndiggørelse ikke har været et kompetenceområde i faget, så er "det (er) jo kommet med alligevel". En af udviklerne peger som en forklaring, at digital myndiggørelse og handlekompetence er indlejret i digitale designprocesser.

I matematik havde man fået tildelt færdigheds- og vidensområder fra alle fire kompetenceområder, og det pegede udviklerne som beskrevet under Tema 1 (Det tværfaglige møde) selv på som en styrke, som en af udviklerne "synes er vigtigt at få skrevet ind i alle fag." Udviklerne så til gengæld gerne, at der i forhold til integrationen i matematikfaget i læreplanen var mere fokus på digital myndiggørelse, "hvor man analyserer verdenen omkring sig (...). Og forholder sig kritisk til den" end på "konstruktionsdelen, som jo lidt er den, hvor man ligesom konstruerer sig frem til en designforståelse". Desuden beskriver en udvikler, at det ville være hensigtsmæssigt med en højere grad af didaktisk frihed til for eksempel at vælge, hvilke matematiske kompetenceområder teknologiforståelse skal spille ind i, så man kan "tage det med, når det giver mening i matematikundervisningen".

I billedkunst var man blevet tildelt færdigheds- og vidensområderne "programmering og konstruktion", "teknologianalyse", "formålsanalyse" og "brugsstudier". Mens det første var en sammensætning af områder fra "teknologisk handleevne" og "digital design og designprocesser", var de sidste tre fv-områder fra "digital myndiggørelse". Selvom billedkunst i forsøget altså var blevet tildelt 3 ud af 5 færdigheds- og vidensområder fra kompetenceområdet digital myndiggørelse, så fagudviklerne ikke, at de i tilstrækkelig grad har fået lov at bidrage til elevernes digitale myndiggørelse: "Billedkunst har så meget at komme med, vi kan bidrage med at udvikle den digitale myndigg $\emptyset$ relse i lige så høj grad, som andre fag kan."

I håndværk og design følte udviklerne sig udfordrede af, at faget kun skulle arbejde med det ene kompetenceområde Digital design og designprocesser: "når man tager et kompetenceområde direkte fra som fag og direkte 1:1 over i fag, som man har gjort med håndværk og design, så mangler man naturligvis nogle ting, der er der i alle de andre kompetenceområder". En anden udvikler uddybede: 
Men, hold kæft hvor har det været irriterende! Det kunne det være rigtigt spændende at bevæge sig ud i, digital myndiggørelse ... der er et uforløst potentiale i håndværk og design i teknologiforståelsesfagligheden ved at vi ikke kan arbejde med digital myndiggørelse ...

I de udviklede prototyper havde udviklerne valgt at udvide perspektivet i forhold til forsøgets fokus på et enkelt kompetenceområde til også at omfatte for eksempel bruger- og feltundersøgelser: "Men det har jo ikke været med begrundelse i teknologiforståelsesfaget, det har jo været fordi, sådan gør man faktisk også i håndværk og design.”

Udviklerne i håndværk og design havde i deres prototyper bygget på den teknologiske handleevne, som eleverne skulle opnå i andre fag, men oplevede, at det voldte problemer for lærerne:

99 ... fordi vi på en eller anden måde indirekte kræver af lærerne, at de faktisk også orienterer sig i teknologisk handleevne og i computational tænkning med algoritmer, der er jo også der, de blokerer og siger "Vrægh", det har ikke ret meget med håndværk og design at gøre det der ...

Ligesom udviklerne for naturfagene pegede på, har også lærerne i håndværk og design manglet et sprog for den nye faglighed: "Der er ikke noget sprog for teknologisk handleevne, de havde ikke noget viden omkring det ...". Der var ikke noget krav om teknologisk handleevne i læseplanen, men som udviklerne har påpeget, har skabelsen af digitale artefakter været afhængig af en sådan teknologisk handleevne, som dermed har været en forudsætning for de forløb, som er blevet lavet til håndværk og design, eftersom de digitale artefakter havde et krav om et digitalt indhold.

I forsøget havde dansk fået tildelt dele af digital myndiggørelse og digital design og designprocesser, som de opfattede som noget, der var tæt på, "det vi ellers bedriver" i danskfaget. Derudover var faget blevet tildelt fv-området "digital sikkerhed", som ifølge udviklerne har været "...rigtig, rigtig svært at finde sådan nogle danskfaglige fænomener, der talte ind i det, uden at det blev... ja, uden at det kom til at virke som et 'add-on'". Mens udviklerne tilsyneladende ikke kunne se relevansen af området digital sikkerhed, har de til gengæld oplevet at mangle computationel tankegang: "...vi har ikke computationel tænkning med i vores, men det er sådan set underliggende hele pivemøjet”. Udviklerne har altså haft et ønske om at arbejde med en samlet faglighed, men de har manglet dele af den.

Samlet set peger udviklerne generelt på en problematik i forhold til tildelingen af færdigheds- og vidensområder. Danskudviklerne 
savnede computationel tankegang, hvorimod udviklerne i billedkunst og håndværk og design oplevede det som en begrænsning, at de ikke havde fået tildelt digital myndiggørelse som område, mens udviklerne i natur/teknologi og fysik/kemi oplevede, at de havde digital myndiggørelse med i deres prototyper, selvom fagene ikke havde fået tildelt dette kompetenceområde. I håndværk og design oplevede udviklerne tilsvarende at måtte trække på teknologisk handleevne, selvom det ikke fremgik som et egentligt fv-område. I matematik var udviklerne til gengæld tilfredse med at have fået fv-områder fra alle fire kompetenceområder, mens fysik/kemi og natur/teknologi umiddelbart ikke problematiserede tildelingen af deres to kompetenceområder. I sidste ende tegner det et meget broget billede af tildelingen af delelementer af teknologiforståelsesfagligheden til de enkelte fag, og i mange af fagene problematiserede udviklerne fraværet af delelementer af den samlede teknologiforståelsesfaglighed i den konkrete tildeling af færdigheds- og vidensområder til de enkelte fag.

\section{Tema 5: Faglige samspilsmuligheder og brud- flader}

Det sidste tema var det potentiale fagudviklerne så i udviklingen af deres fag gennem et samspil med teknologiforståelse. Når udviklerne pegede på, hvordan teknologiforståelse ville kunne bidrage til deres fag, kom de også ind på brudflader, hvor de ikke havde fundet et frugtbart overlap mellem teknologiforståelse og deres faglighed.

Udviklerne i natur/teknologi og fysik/kemi oplevede, at teknologiforståelse kunne "gøre nogle ting i en eller anden grad synligt, som ellers var usynligt" og "øge begrebsindholdet". Samtidig pegede udviklerne på, at de iterative designprocesser "skubber jo også noget væk fra noget tavleundervisning". Udviklerne omtalte denne designtilgang, som dén kompetence, der løftede computationel tankegang frem i fagene, og som løftede dele af den digitale myndiggørelse frem mod en sammenhængende teknologiforståelsesfaglighed: 
Computationel tankegang er et godt redskab til at arbejde med digital design og designprocesser og digital design og designprocesser er godt til at vurdere digitale artefakter, både dem man selv har produceret, og dem som andre producerede, hvis man skal kigge på noget, som ikke er ens eget, altså som eleverne selv udvikler, men hvis man skal kigge på apps, der er udviklet til et eller andet, så... øhm, ja, så i hvert fald de to kompetenceområder spiller rigtig godt sammen, og de spiller rigtig godt sammen med naturfagene, synes jeg.

Således havde udviklerne i natur/teknologi og fysik/kemi oplevet, at teknologiforståelse kunne bidrage til en faglig udvikling i deres fag. Udviklerne oplevede, at det i starten af projektet var en udfordring at få bragt teknologien "ind i faget" og meget udviklingstid blev brugt på "at lære om teknologi og hvordan det overhovedet er sat sammen". Over tid blev der udviklet en basis for at anvende den nye teknologiske indsigt som en basis for refleksioner over teknologiernes betydning og rolle. De matematikfaglige udviklere fortalte, at de generelt oplevede, at der havde været et meningsfuldt samspil mellem matematik- og teknologiforståelsesfaglighederne. Desuden pegede de i lighed med udviklerne i natur/teknologi og fysik/kemi på nogle af de didaktiske tilgange fra teknologiforståelse, som "bud på en modernisering" af deres fag. I billedkunst havde udviklernes udgangspunkt været, "at de to fagligheder ikke skulle være et appendiks til hinanden, men at de faktisk skulle udvikle hinanden, de skulle udfordre hinanden", men udviklerne oplevede udfordringer med tilgangen til teknologiforståelse, som de så som naturfaglig og omverdens-problemorienteret. Selvom udviklerne gav udtryk for, at de udviklede prototyper til en vis grad var "troværdige over for faget [billedkunst], som giver mening", oplevede de, at det problemløsende element samt kravene om programmering og digitale artefakter "lægger faget ned i en ramme, som faget ikke rigtigt kan være i, den fjerner lidt den her fantasitænkning". Udviklerne oplevede nemlig ikke, at der var plads til det mere "undersøgende, fabulerende, ikke facit-orienterede", som de i højere grad så som en del af billedkunsts identitet, og derfor pegede de på, at der var et behov for, at teknologiforståelse i billedkunst:

99 finder sin egen retning i forhold til at være problemløsende: Om det nødvendigvis skal være udgangspunktet, det tror jeg ikke for billedkunstfaget altid skal være et problem. Det kan i højere grad være en nysgerrighed eller en undren på noget, ikke? 
Samtidig så udviklerne et potentiale i, at billedkunst ville kunne bidrage til udvikling af sådanne mindre problemorienterede tilgange til teknologiforståelse. Udviklerne mente også, at det var vigtigt, at teknologiforståelses-fagligheden fremover ville komme til at indeholde de mere æstetiske, fabulerende tilgange, som de ikke oplevede, at der havde været plads til i forsøget:

99 vi er ikke ude $\mathrm{i}$ at uddanne kodere, vi er ude i at uddanne og danne nogle unge mennesker, der forstår det samfund, de er en del af. Og der har billedkunst altså også en forpligtelse, for hvis vi alene lægger den teknologiforståelsesfaglighed over i en naturfagskontekst, så svigter vi de elever, der ikke lærer den vej ind, men som lærer en mere praktisk-musisk vej ind, kan man sige.

Udviklerne i dansk pegede ligesom udviklerne fra billedkunst på, at de oplevede, at teknologiforståelse i forsøget havde en manglende vægt på humanistiske, kunstneriske og æstetiske tilgange til fremtidsforestillinger. Udviklerne oplevede, at der var brug for en danskfaglig nytænkning, som rettede blikket mod verden på en anden måde end danskfagets typiske perspektiveringer og de oplevede, at teknologiforståelse havde et potentiale til at katalysere en sådan nytænkning, men de oplevede også et behov for at tone flere kompetenceområder på danskfaglige præmisser. Udviklerne mente altså et potentiale for, at teknologiforståelse kunne bidrage til en fagudvikling, men de oplevede, at der var behov for, at denne udvikling ikke udelukkende tog udgangspunkt i den forsøgsfaglighed, de havde arbejdet med.

I håndværk og design oplevede udviklerne den forståelse af designprocessen, som kom fra teknologiforståelse, som et velkomment bidrag til deres fag. Det var både gældende for "de komplekse problemstillinger", for fokus på "rammesættelse" og for "...hele den der forståelse af konstruktionsfasen og loops og det, at man har ord som argumentation og introspektion, altså det har været fantastisk". Udviklerne pegede på, at "der er noget, som faget allerede godt kan, men som bliver kvalificeret og løftet med teknologiforståelse". Det gælder ifølge udviklerne for eksempel i forhold til at anvende digitale (fabrikations-) teknologier, "... der faktisk kan bruges lige nu uden teknologiforståelse .... Her har man i forvejen kunnet bruge maskiner til at bearbejde materiale, men ifølge udviklerne bidrager teknologiforståelsesfagligheden ved, at du kan "... forholde dig til hele maskinen ... Hvordan er den designet? Og samtidigt også måske kunne perspektivere det lidt til et samfundsperspektiv..." I det hele taget peger udviklerne i håndværk og design altså på, at teknologiforståelse har et potentiale i forhold til at skabe en udvikling i deres fag.

I samfundsfag ser udvikleren et potentiale i teknologiforståelse 
som en vej til et fokus på "hvordan teknologierne påvirker både politik og økonomi og de sociologiske forhold, altså hvordan vi er mellem mennesker". Udvikleren oplever imidlertid, at det fokus, der er i fors $\emptyset$ get, har været på fremstilling af digitale artefakter har taget for meget fokus:

99 Man skal designe noget der kan - en teknologisk artefaktdims der kan løse et eller andet, (...) og så bruger man nogle teknologier til en masse ting, som man bliver klogere på, men stillingtagen i sidste ende, ligger udenfor teknologierne.

Udvikleren opfattede det som mere relevant, at den teknologiske forestillingsevne, som hun oplever som en central del af forsøget, blev drejet mere over mod:

99 en samfundsmæssig forestillingsevne, hvad vil vi med vores samfund eller vores fællesskaber eller vores liv i det hele taget? Og der synes jeg så den der teknologiforståelsesfaglighed lægger meget op til, vi skal finde ud af, hvordan vi skal bruge teknologier til at løse de problemer, vi måtte have.

På tværs af alle fagene pegede udviklerne på, at teknologiforståelse havde potentiale til at bidrage til en faglig udvikling i deres fag. Særligt i håndværk og design, natur/teknologi, fysik/kemi og matematik havde udviklerne allerede set konturerne af en sådan udvikling i forbindelse med forsøget, mens udviklerne i samfundsfag, billedkunst og dansk i højere grad oplevede, at der var et behov for at gentænke, hvad teknologiforståelse skulle betyde i deres fag. I samfundsfag efterlyste udvikleren et større fokus på koblingen til en samfundsmæssig forestillingsevne og teknologiernes påvirkning af os som mennesker og som samfund, mens udviklerne i dansk og billedkunst efterlyste en mindre problemløsningsorienteret tilgang til æstetiske processer med digitale teknologier og en diskussion af kravene om og til digitale artefakter.

\section{Sammenfatning og diskussion}

Denne artikel er baseret på interviews med fagudviklere, som har haft til opgave at udvikle prototyper på undervisningsforløb til læreres afprøvning af teknologiforståelse. Disse fagudviklere er kommet ind i projektet med forskellige erfaringer med de involverede fagligheder, men vi antager, at de er udvalgt af deres ledelser som de bedst egnede til opgaven. Derfor kan deres position i projektet karakteriseres 
som en most-likely critical case (Flyvbjerg, 2010). Når disse udviklere derfor peger på elementer, der i deres øjne ikke er lykkedes, kan man derfor antage, at det også vil gælde for flere andre i samme situation. Der er til gengæld mange faktorer, der karakteriserer denne situation. Fagudviklerne har dels skullet forholde sigt til fagformål, fælles mål, læseplaner og undervisningsvejledninger og dels til rammerne i projektet, hvor der blev udstukket krav til implementering af fagligheden fra projektejer, en prototypeskabelon og feedback processer, som var en del af forsøget. Når fagudviklerne forholder sig til en given problematik, som for eksempel forholdet mellem fokus på komplekse problemer og æstetiske processer, ved vi således ikke, om det sker med udgangspunkt i implementeringskrav i forsøget eller med udgangspunkt i beskrivelserne i de overordnede styringsdokumenter. Vi har heller ikke undersøgt en eventuel sammenhæng mellem en udviklergruppes samlede erfaring med teknologiforståelse og dennes holdning til fagligheden eller elementer af fagligheden.

Som nævnt ovenfor oplevede alle udviklerne, at teknologiforståelse havde et potentiale for at bidrage til udvikling af deres fag, og dermed satte de generelt ikke spørgsmålstegn ved relevansen af at styrke elevernes teknologiforståelse. Til gengæld oplevede fagudviklerne i dansk, samfundsfag og billedkunst, at forsøgsfagligheden i dens aktuelle form ikke realiserede dette potentiale i netop deres fag. I analyserne af de udførte interviews med fagudviklere opstod fem temaer, som diskuteres i dette afsnit. Det første var de faglige samspilsmuligheder og brudflader (Tema fem), som udviklerne pegede på. For især dansk, samfundsfag og billedkunsts vedkommende oplevede udviklerne et behov for et stærkere grundlag for, hvordan teknologiforståelse med fordel kunne integreres i deres fag.

Tema fire var udviklernes opfattelse af, hvad det har betydet, at bestemte kompetence- og f/v-områder blev tildelt deres fag. Der var betydelige forskelle på, hvordan fagudviklere fra de forskellige fag så på tildelingen af færdigheds- og vidensområder. Hvor udviklerne i for eksempel matematik oplevede at have fået tildelt meningsfulde elementer af alle fire kompetenceområder, oplevede andre udviklere, i for eksempel dansk og håndværk og design, at de manglede nogle af kompetenceområder, de ikke var blevet tildelt. Der kan være flere forklaringsmodeller for dette. Det kan for eksempel være, at fagligheden er vanskelig at få til at fungere i fragmenter og måske dermed, at der er en høj grad af sammenhæng mellem de forskellige kompetenceområder i teknologiforståelsesfagligheden, men det kan også være, at udviklerne i disse fag bedre ville have kunnet få andre fv-områder til at fungere.

Alle fagudviklerne omtalte digital myndiggørelse som væsentligt, og selvom området ikke er indtænkt i natur/teknologi og fysik/kemi 
valgte udviklerne alligevel at arbejde med den del. Mens natur/teknologi, fysik/kemi samt matematik har positive erfaringer med de tildelte elementer af fagligheden, udtrykker fagudviklerne i de andre fire fag en række varianter og bud på, hvordan tildelingen af kompetenceområderne kunne have understøttet en mere teknologifaglig relevant retning. Fagudviklerne i billedkunst efterlyste for eksempel digital myndiggørelse, mens man i dansk godt kunne have undværet færdigheds- og vidensområdet om digital sikkerhed og efterspørger en anden toning af kompetenceområdet teknologisk handleevne. I håndværk og design fik man kun ét kompetenceområde, og det har ifølge udviklerne været med til at reducere fagligheden. I samfundsfag fik man et helt teknologifagligt område, som den faglige udvikler ikke finder var fyldestgørende. Der er altså ifølge udviklerne en hel del at gennemtænke i forhold til, hvad det reelt vil sige at integrere en delmængde af en større faglighed, som det er udtrykt i styredokumenter for afprøvningsforsøget. Omvendt er alle faglige udviklere optagede af, at den faglighed de har integreret, skal kunne langt mere, og de efterspørger alle mere faglighed samt flere og mere relevante muligheder for at sætte den nye faglighed i spil. Til gengæld udtaler de samstemmende, at det i højere grad bør foregå på fagenes præmisser, så fagligheden kan udvikles indefra med nogle realiserbare og relevante elementer fra det selvstændige fag.

I forhold til de definitioner af teknologi, som teknologiforståelsesfagligheden baserede sig på (Tema tre) og i særdeleshed i forhold til kravene til og om digitale artefakter i undervisningen, opstod der i en række fag barrierer, som udviklerne oplevede som unødvendige. I teknologiforståelsesfagligheden har elevers produktion af digitale artefakter en central position. I nogle fag har dette ifølge fagudviklerne medført faglig udvikling, mens det for andre har fungeret som en barriere for udviklingen af fagligheden. Fagudviklerne lader her til at have opfattet det sådan, at tværfagligheden og fagudviklingen i for høj grad er sket på teknologiforståelsens præmisser. Hvor teknologiforståelse i sin nuværende udformning er baseret på en samtænkning af participatory design og computational thinking, som begge har anvendelse af digitale teknologier og artefakter som genstandsfelt, oplevede nogle fagudviklere altså et behov for at udfordre dette genstandsfelt.

Det andet tema, som kodningen havde identificeret, var de fællesheder og overlap i begreber og fagsprog (Tema to), som udviklerne oplevede. Med rod i de to førnævnte forskningstraditioner har teknologiforståelse fra starten haft et vokabular baseret på disse. Her har nogle begreber som for eksempel design og modellering haft nogle betydninger, som var anderledes end dem, der i forvejen var i nogle af fagene. Tilsvarende har nogle af udviklerne oplevet, at de i forvejen havde indhold i deres fag, som der nu kom nye begreber for, 
eksempelvis introspektion og fabrikation, som fik en dobbeltbetydning i dansk og billedkunst. Det har ifølge udviklerne skabt problemer, når nye begreber blev brugt om noget, udviklerne oplevede, var i faget i forvejen (men som hed noget andet), og når eksisterende begreber blev brugt om noget andet, end de normalt blev brugt i faget. I det hele taget pegede udviklerne på fagsproget som en stor udfordring. Problematikken er velkendt og rækker ud over afprøvningsforsøget, idet udviklingen af nye begreber og begrebsligheder, der på sigt kan udvikle sig til et fagsprog eller del af et fagsprog, altid har været et udviklings- og forskningsfelt i den fagdidaktiske skoleforskning (Nielsen 1998, Krogh, Qvortrup \& Christensen, 2016). I lyset af blandt andet udviklernes erfaringer er der i vores optik behov for en forskning, der kan bidrage til systematiske undersøgelser af begrebsligheder og tilkoblingsmuligheder imellem teknologiforståelse og eksisterende fag- og fagdidaktikker.

Det første tema, som opstod i analysen, kan også ses som overordnet i forhold til de andre fire temaer. I udviklernes refleksioner over veje til et tværfagligt møde mellem det etablerede fag og teknologiforståelsesfagligheden (Tema et), er der tydelige forskelle mellem fagene. Hvor for eksempel udviklerne i natur/teknologi og fysik/kemi oplevede, at den største udfordring var kompetenceudvikling, oplevede udviklerne i dansk og billedkunst, at der ud over udvælgelsen af fv-områder var grundlæggende udfordringer i forhold til fagsprog, teknologidefinitioner og den problembaserede didaktik.

På tværs af fag opfattede udviklerne i naturfag overordnet fagligheden som relevant, så når den ikke i samme grad blev opfattet som relevant i dansk og billedkunst i den givne udformning, kan det hænge sammen med partikulære forhold som de føromtalte udvælgelser af del-elementer af fagligheden, den problembaserede didaktik, definitionerne på relevante teknologier og artefakter og sammenstød mellem fagsprog. Dermed peger analysen på, at netop disse temaer er værd at holde øje med i fremtidig udvikling af teknologiforståelsesfagligheden. Og på tværs af de undersøgte fag pegede udviklerne som nævnt alle sammen på, at deres teknologiforståelse havde en relevans og et potentiale for at bidrage til udviklingen af fagene. I dansk og billedkunst opfattede udviklerne fagligheden som naturfagligt præget, ligesom de savnede plads til mindre målrettede æstetiske processer, men samtidig opfattede de det som problematisk, hvis teknologiforståelse fremover skulle blive et rent naturfagligt anliggende. Tværtimod oplevede de et behov for at trække teknologiforståelse i retning af humanistiske, æstetiske læreprocesser. 


\section{Konklusion}

Teknologiforståelse er som nævnt i begyndelsen af denne artikel en ny og sammensat faglighed, som er baseret på særligt forskningsområderne computational thinking og participatory design. Inden for forskning i participatory design, findes international og national forskningslitteratur om digitale designprocesser med børn i et myndiggørende perspektiv, men disse er ikke tænkt ind i eksisterende fag i skolen og tager ikke udgangspunkt i teknologiforståelse som en samlet faglighed delt ud i delfagligheder i de eksisterende fag. Vores undersøgelser er baseret på Forsøg med teknologiforståelse i folkeskolens obligatoriske undervisning, som er det første stor-skala-projekt med teknologiforståelse i den danske udmøntning. Empirien, som er baseret på interviews med fagudviklere fra forsøget, peger på fire potentielle barrierer for et reelt fagmøde og dermed for integration af teknologiforståelse i eksisterende fag: Manglende samtænkning af begreber og fagsprog, divergerende definitioner af teknologi, manglende overlap og relevans i tildelingen af delelementer af fagligheden og manglende plads til faglig udvikling.

\section{Referencer}

Barr, V. \& Stephenson, C. (2011). Bringing computational thinking to K-12: what is Involved and what is the role of the computer science education community? ACM Inroads, 2(1), 48-54. DOI:10.1145/1929887.1929905

Bekker, T., Bakker, S., Douma, I., Van Der Poel, J. \& Scheltenaar, K. (2015). Teaching children digital literacy through design-based learning with digital toolkits in schools. International Journal of Child-Computer Interaction, 5, 29-38. DOI: 10.1016/j. ijcci.2015.12.001

Brennan, K. \& Resnick, M. (2012). New frameworks for studying and assessing the development of computational thinking. Proceedings of the 2012 annual meeting of the American educational research association, Vancouver, Canada (Vol. 1, s. 25).

Brennan, K. (2015). Beyond right or wrong: Challenges of including creative design activities in the classroom. Journal of Technology and Teacher Education, 23(3), 279299.

Børne- og Undervisningsministeriet. (2018-2021). Teknologiforståelse ifolkeskolen. https://tekforsøget.dk/om-forsoget

Børne- og Undervisningsministeriet. (2018a). Kommissorium for den rådgivende ekspertskrivegruppe for forsøgsprogram for styrkelse af teknologiforståelse $i$ folkeskolens obligatoriske undervisning. Hentet 23. marts, 2021, fra https://www.uvm. $\mathrm{dk} /$-/media/filer/uvm/udd/folke/pdf18/jan/180124-kommissorium-for-raadgivendeekspertskrivegruppe-teknologiforstaaelse.pdf 
Børne- og Undervisningsministeriet. (2018b). Loseplan for forsøgsfaget teknologiforståelse.

Børne- og Undervisningsministeriet. (2018c). Tilføjelse til loeseplan i matematik. Forsøgsprogrammet med Teknologiforståelse.

Børne- og Undervisningsministeriet. (2019). Ordliste over fagbegreber i teknologiforståelse ifolkeskolen.

Børne- og Undervisningsministeriet. (2020). Midtvejsevaluering - forsøg med teknologiforståelse ifolkeskolens obligatoriske undervisning .

Børne- og Undervisningsministeriet. (2021a). Bekendtgørelse af lov om folkeskolen. Lovtidende A. København.

Børne- og Undervisningsministeriet. (2021b). It og medier.

Caspersen, M. E., Iversen, O. S., Nielsen, A. \& Mussaeus, L. H. (2018). Computational Thinking - hvorfor, hvad og hvordan? IT-Vest \& Villum Fonden.

Christensen, K. S., Hjorth, M., Iversen, O. S. \& Smith, R. C. (2019). Understanding design literacy in middle-school education: Assessing students' stances towards inquiry. International journal of technology and design education, 29(4), 633-654. DOI:10.1007/s10798-018-9459-y

Chu, S. L., Angello, G., Saenz, M. \& Quek, F. (2017). Fun in Making: Understanding the experience of fun and learning through curriculum-based Making in the elementary school classroom. Entertainment Computing, 18, 31-40. DOI: 10.1016/j. entcom.2016.08.007

Creswell, J. W. (2008). Grounded Theory Designs. I: Educational Research (3. udg.). Pearson.

Cross, N. (2011). Design thinking: Understanding how designers think and work. Berg.

Ehn, P. (1988). Work-oriented design of computer artifacts. [Doktorafhandling, Arbetslivscentrum, Stockholm].

Education, Audiovisual and Culture Executive Agency (EACEA). (2012). Key Data on Education in Europe 2012. European Commission.

Flyvbjerg, B. (2010). Fem misforståelser om casestudiet. I: S. Brinkmann \& L. Tanggard (red.), Kvalitative metoder (s. 463-487). Hans Reitzels Forlag.

Hjorth, M., Christensen, K. C., Iversen, O. S. \& Smith, R. C. (2017). Digital Technology and design processes II: Follow-up report on FabLab@ School survey among Danish youth. Aarhus Universitet.

Iversen, O. S., Smith, R. C., Blikstein, P., Katterfeldt, E.-S. \& Read, J. C. (2015). Digital fabrication in education: Expanding the research towards design and reflective practices. International Journal of Child-Computer Interaction, 5, 1-2. DOI: 10.1016/j. ijcci.2016.01.001

Iversen, O. S., Dindler, C. \& Smith, R. C. (2020). Computational Empowerment: Participatory Design in Education. CoDesign: International Journal of CoCreation in Design and the Arts, 16(1), 66-80. DOI:10.1080/15710882.2020.1722173

Katterfeldt, E. S., Dittert, N. \& Schelhowe, H. (2015). Designing digital fabrication learning environments for Bildung: Implications from ten years of physical computing workshops. International Journal of Child-Computer Interaction, 5, 3-10. DOI: 10.1016/j.ijcci.2015.08.001

Krogh. E, Qvortrup, A. \& Christensen. T. S. (2016). Almendidaktik og fagdidaktik. Frydenlund.

Löwgren, J. \& Stolterman, E. (2004). Thoughtful interaction design: A design perspective on information technology. MIT Press. 
Maykut, P. \& Morehouse, R. (1994). Beginning Qualitative Research. The Falmer Press.

Nielsen, F. V. (1998). Almen Musikdidaktik. Akademisk Forlag.

Potter, W. J. (1996). An Analysis of Thinking and Research about Qualitative Methods. Lawrence Erlbaum.

Smith, R. C., Iversen, O. S. \& Hjorth, M. (2015). Design thinking for digital fabrication in education. International Journal of Child-Computer Interaction, 5, 20-28.

DOI: 10.1016/j.ijcci.2015.10.002

Slot, M., Lorentzen, R.F. \& Hansen T.I. (2021). Hvordan integreres teknologiforståelse i dansk? Learning tech, 10. Læremiddel.dk.

Wagner, M.-L., Iversen, O. S. \& Caspersen, M. E. (2020). Teknologiforståelsens rationale: På vej mod computational empowerment i den Danske grundskole. Unge Pcedagoger, 1(2020), 2-15.

Weintrop, D., Beheshti, E., Horn, M., Orton, K., Jona, K., Trouille, L. \& Wilensky, U. (2016). Defining computational thinking for mathematics and science classrooms. Journal of Science Education and Technology, 25(1), 127-147.

Wing, J. M. (2006). Computational thinking. Communications of the ACM, 49(3), 33-35. DOI: $10.1145 / 1118178.1118215$

\section{Bilag 1}

\section{Tabel 1.}

Overblik over, hvilke trin og fag der i forsøget har integreret teknologiforståelsesfaglighed.

\begin{tabular}{l|l|l|l|l|l} 
& Dansk & Matematik & $\begin{array}{l}\text { Nat/tek } \\
\text { Fysik/kemi }\end{array}$ & $\begin{array}{l}\text { Billedkunst } \\
\text { Håndværk/ } \\
\text { design }\end{array}$ & Samfundsfag \\
\hline Indskoling & & & N/T & BK & \\
\hline Mellemtrin & & & N/T & H/D & \\
\hline Udskoling & & & F/K & &
\end{tabular}


Tabel 2 viser en oversigt over fagene og de kompetenceområder fra fagene som de relevante kompetence/færdigheds- og vidensmålsområder fra Fælles Mål for Teknologiforståelse i fag er lagt ind under:

Tabel 2.

Overblik over, hvilke trin og fag der i

forsøget har integreret teknologiforståel-

sesfaglighed.

\begin{tabular}{|c|c|c|c|c|c|c|}
\hline & Dansk & Matematik & $\begin{array}{l}\text { Nat/tek } \\
\text { Fysik/kemi }\end{array}$ & Billedkunst & Samfundsfag & $\begin{array}{l}\text { Håndværk/ } \\
\text { design }\end{array}$ \\
\hline $\begin{array}{l}\text { Digital } \\
\text { myndiggørelse }\end{array}$ & $\begin{array}{l}\text { Kommuni- } \\
\text { kation }\end{array}$ & & & $\begin{array}{l}\text { Selvstændige } \\
\text { f/v-områder } \\
\text { under fagets } \\
\text { kompetence- } \\
\text { områder: } \\
\text { — Program- } \\
\text { mering og } \\
\text { konstruk- } \\
\text { tion } \\
\text { under KO } \\
\text { — Billedfrem- } \\
\text { stilling } \\
\text { — Teknologi- } \\
\text { analyse } \\
\text { under } \\
\text { Billed- } \\
\text { analyse } \\
\text { — Brugs- } \\
\text { studier } \\
\text { under } \\
\text { Billed- } \\
\text { kommuni- } \\
\text { kation }\end{array}$ & & \\
\hline
\end{tabular}




\begin{tabular}{|c|c|c|c|c|c|}
\hline $\begin{array}{l}\text { Digital design } \\
\text { og digitale } \\
\text { design- } \\
\text { processer }\end{array}$ & Fremstilling & $\begin{array}{l}\text { Selvstændigt } \\
\text { kompetence- } \\
\text { område } \\
\text { Teknologi- } \\
\text { forståelse, } \\
\text { hvor DDoDD } \\
\text { er f/v- } \\
\text { område }\end{array}$ & $\begin{array}{l}\text { Undersøg- } \\
\text { else }\end{array}$ & $\begin{array}{l}\text { Selvstændigt } \\
\text { kompetence- } \\
\text { område med } \\
\text { tilknyttede } \\
\text { færdigheds- } \\
\text { og vidensmål } \\
\text { (mellemtrin) }\end{array}$ & $\begin{array}{l}\text { Selvstændigt } \\
\text { kompetence- } \\
\text { område med } \\
\text { tilknyttede } \\
\text { færdigheds- } \\
\text { og vidensmål } \\
\text { (mellemtrin) }\end{array}$ \\
\hline $\begin{array}{l}\text { Computa- } \\
\text { tionel } \\
\text { tankegang }\end{array}$ & & $\begin{array}{l}\text { Selvstændigt } \\
\text { kompetence- } \\
\text { område } \\
\\
\text { Teknologi- } \\
\text { forståelse, } \\
\text { hvor CT } \\
\text { fylder en del } \\
\text { i f/v- } \\
\text { områderne }\end{array}$ & Modelling & & \\
\hline $\begin{array}{l}\text { Teknologisk } \\
\text { handleevne }\end{array}$ & & $\begin{array}{l}\text { Selvstændigt } \\
\text { kompetence- } \\
\text { område } \\
\text { Teknologi- } \\
\text { forståelse, } \\
\text { hvor TH er en } \\
\text { del af f/v- } \\
\text { områderne }\end{array}$ & & & \\
\hline
\end{tabular}

\section{Særlige færdigheds-vidensområder for enkelte fag}

\begin{tabular}{c|l}
\hline Dansk & Digital sikkerhed, placeret under kompetenceområdet Kommunikation \\
\hline Nat/tek & $\begin{array}{l}\text { Digitale teknologier i naturfag, hverdag og samfund placeret under kompetenceområdet } \\
\text { Perspektivering. } \\
\text { Argumentation (TF) placeret under kompetenceområdet Kommunikation. }\end{array}$ \\
\hline Samfundsfag & $\begin{array}{l}\text { Selvstændigt kompetenceområde: Digitale artefakter og teknologier } \\
\text { i samfundet. Desuden f/v-område "Medier og politik" under kompetenceområdet Politik. }\end{array}$
\end{tabular}

